\title{
Population trends and diversification of breeding habitats of Peregrine Falcon (Falco peregrinus) in the Czech Republic since 1990
}

\author{
Václav BerAN ${ }^{1,2 *}$, Josef VRÁnA ${ }^{1} \&$ David HoraL ${ }^{3,4}$ \\ Received: September 10, 2018 -Revised: September 27, 2018 - Accepted: November 04, 2018
}

This is a contribution submitted to the Proceedings of the World Conference on the Peregrine Falcon in Budapest in September 2017.

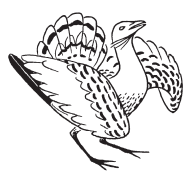

Beran, V., Vrána, J. \& Horal, D. 2018. Population trends and diversification of breeding habitats of Peregrine Falcon (Falco peregrinus) in the Czech Republic since 1990. - Ornis Hungarica 26(2): 121-129. DOI: 10.1515/orhu-2018-0020

covered fro a breeding after this interval was confirmed in 1995. The increase of the population size accelerated after 2000 and it is still growing despite the limited amount of suitable natural breeding opportunities. There were 89 known pairs in 2016, 70 of them were proven to breed with altogether at least 121 reared young. Several breeding attempts on historical buildings in city-centres were recorded up to 2002 (in Prague and Pilsen), but this breeding habitat was abandoned later. More and more pairs are nowadays breeding on industrial buildings. The first breeding on a power plant chimney, $300 \mathrm{~m}$ above the ground was discovered in 2010. Moreover, 16 breeding pairs were found on industrial buildings in 2016 (mainly tall chimneys or cooling towers and power-plant buildings), all of them breeding in nest boxes. The colonization of industrial buildings started in western part of the Czech Republic and continues eastwards every year. Currently, the easternmost colonized building is in Mladá Boleslav. We have no recent tree-breeding pairs and all eight published historical cases are at least doubtful. Most of the observed Peregrines ringed abroad came from Germany, indicating a strong influence of German population on restoration of the population in the Czech Republic. Within these recoveries, some of Peregrines were released in the tree-breeding population restoration project in Germany and Poland, but all these birds bred on rocks.

Keywords: Peregrine Falcon, Czech Republic, population, nest boxes, natural breeding sites

Összefoglalás A Cseh Köztársaság területén élő vándorsólyom (Falco peregrinus) populáció az 1960-1980-as évek alatt csaknem teljesen kipusztult (0-3 költőpár). Ezen időszak után az első sikeres költést 1995-ben regisztrálták. A populációméret növekedése a 2000-es év után felgyorsult, és az alkalmas fészkelési lehetőségek korlátozott száma ellenére továbbra is tart. 2016-ban a 89 ismert költőpárból 70 nevelt fel összesen legalább 121 fiatal egyedet. 2002-ig számos költési kísérletet jegyeztek fel a városközpontok müemlék épületein (Prágában és Pilsenben), de a madarak ezeket a helyeket később elhagyták. Napjainkban egyre több pár fészkel ipari épületeken. 2010-ben írták le az első olyan költést, amely egy erőmü kéményén történt 300 méteres magasságban, 2016-ban már 16 költőpárt találtak ipari épületeken (föként magas kéményeken, hütőtornyokon, illetve erőmüveken), melyek közül mindegyik költőládában fészkelt. A vándorsólymok először a Cseh Köztársaság területének nyugati részén kezdték kolonizálni az ipari épületeket, majd ez a terjeszkedés minden évben a keleti területek felé folytatódott. A legkeletebbi kolonizált ipari épület jelenleg Mladá Boleslav területén van. Egyetlen olyan költőpárról sem tudni, amely fán fészkel, a nyolc korábbi publikált eset is kétséges. A megfigyelt, külföldi gyürüs sólymok többsége Németországból származik, ami jelzi a német populáció szerepét a Cseh Köztársaság területén élő állomány helyreállításában. Néhány visszafogott egyedet a fán fészkelő populáció megerősítését célzó projekt keretein belül engedtek el Németországban és Lengyelországban, de ezek a madarak később mind sziklákon költöttek.

Kulcsszavak: vándorsólyom, Cseh Köztársaság, populáció, fészekodú, természetes fészkelőhelyek 
${ }^{1}$ ALKA Wildlife o.p.s, o.p.s., Lidérovice 62, 38001 Dačice, Czech Republic, e-mail: lutra@email.cz (VB), pomarina@seznam.cz (JV)

${ }^{2}$ Town Museum Ústí nad Labem, Masarykova 1000/3, 40001 Ústi nad Labem, Czech Republic

${ }^{3}$ Czech Society for Ornithology, Na Bělidle 34, 15000 Praha-Smichov, Czech Republic, david.horal@seznam.cz ${ }^{4}$ Nature Conservation Agency of the Czech Republic, Brno regional centre, Kotlárská 51, 60200 Brno, Czech Republic

* corresponding author

\section{Introduction}

The Peregrine Falcon (Falco peregrinus) has probably never been a common raptor species in the Czech Republic. There is scarce historical data from the $19^{\text {th }}$ century, but it is hard to establish the real population size for those days (Š́r 1890). Dramatic fluctuations of the population led up to a total extinction during the 1960s. Reoccupation of our country in the early 1990 s correlates with the DDT ban and with the increase of the European population in general. First breeding was confirmed in 1995 and since then, the Czech population continues to increase despite the limited amount of suitable breeding places on the rock cliffs. Consequently, Peregrines started to breed on industrial buildings as well in 2010. Also, less suitable rock cliffs (suboptimum breeding habitats) were occupied. Up to 2001, Peregrines bred only in the mountain border zone (with the exception of two pairs breeding in the towns of Prague and Pilsen), but they started to breed in more populated areas. Breeding on historical buildings (churches) was recorded only in Prague (Peške 1995, 1997) and Pilsen (Hruška et al. 2000, Mlíkovský \& Hruška 2000) for several consecutive years and was probably related to release of captive-bred individuals in these towns. Recently, breeding on industrial buildings is more common (Hlaváč \& Beran 2011). The most interesting case was observed in the region of South Moravia between 1997-2003, where a pair of Peregrines occupied a large hollow in a large poplar-tree in the artificial "Nové Mlýny" lake (and later a wooden nestbox installed on the same tree), but this pair has never bred successfully, most probably they never laid clutch (Horal 2013).

The Czech Republic is a medium-sized country $\left(78,866 \mathrm{~km}^{2}\right)$ in Central Europe. The population is cca. 10.5 million people living in an average density of $134 / \mathrm{km}^{2}$, which means that not much space is left for wildlife. The most remoted places are concentrated especially in the mountainous border areas. In general, there are not so many natural breeding areas - rock cliffs. Those few are scattered in the border mountain ranges, few sand-stone, limestone and karst areas and deep canyons of larger rivers. The majority of the rocky areas are situated in protected areas (especially in 4 national parks - 1.5\% and in 26 protected landscape areas $-13.6 \%$ of the total country area). Unfortunately, most of the rock cliffs are under a heavy pressure by tourism. Special precautions (mainly no entrance and disturbance) have to be undertaken during the breeding season on most of the natural breeding sites. There are 41 special protected areas - SPAs as a part of Natura 2000 network (ca 9\% of the country area) but only 2 of them are designated for Peregrine Falcons (Labské Pískovce - 12 pairs, Broumovsko - 7 pairs in 2017). In SPA Jeseníky (originally not designated for Peregrine Falcon), population reached 16 breeding pairs in 2017 (Šaj 2018). On the contrary, industrial buildings are distributed mainly in the lowlands and therefore supplement the 


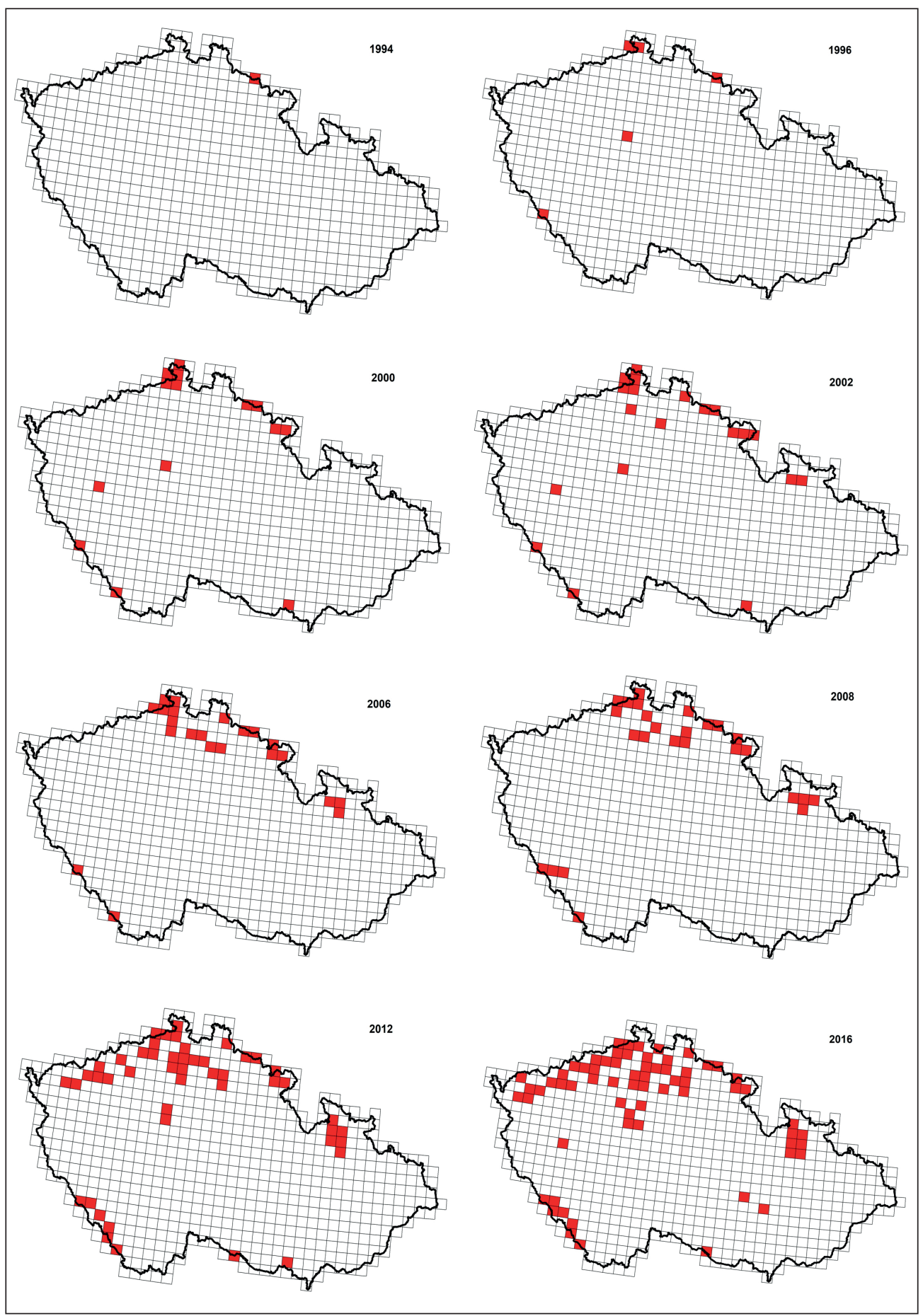

Figure 1. Distribution map of the Peregrine Falcon from 1994 to 2016 in the Czech Republic 1. ábra A vándorsólyom elterjedési térképe a Cseh Köztársaság területén 1994 és 2016 között 
mainly mountainous natural breeding sites. Artificial breeding opportunities (mainly nest boxes) are installed at industrial buildings to provide safe breeding. The only source of disturbance (occasional technical controls) can be eliminated through appropriate communication with owners.

\section{Results and Discussion}

Maps on Figure 1 show the recolonization of the Czech Republic since 1994. Continuous population growth (see graph on Figure 2) is well visible on the distribution maps as well. Border mountain areas (less populated) were reoccupied first and Peregrines were restricted to them up to 2001 (excluding two pairs breeding in Prague and Pilsen). Sandstone areas in northern Bohemia were occupied since 2002. Along with the continuous increase in numbers, further range expansion happened in 2010, when further areas of northern Bohemia were occupied and first pairs on industrial buildings settled down in north-west Bohemia. Expansion continues in the next years, more and more grid squares in north-west Bohemia are occupied every year. Finally, two breeding pairs took over historical breeding grounds in southern Moravia in 2016. Slow expansion to other parts of the Czech Republic is expected in the future.

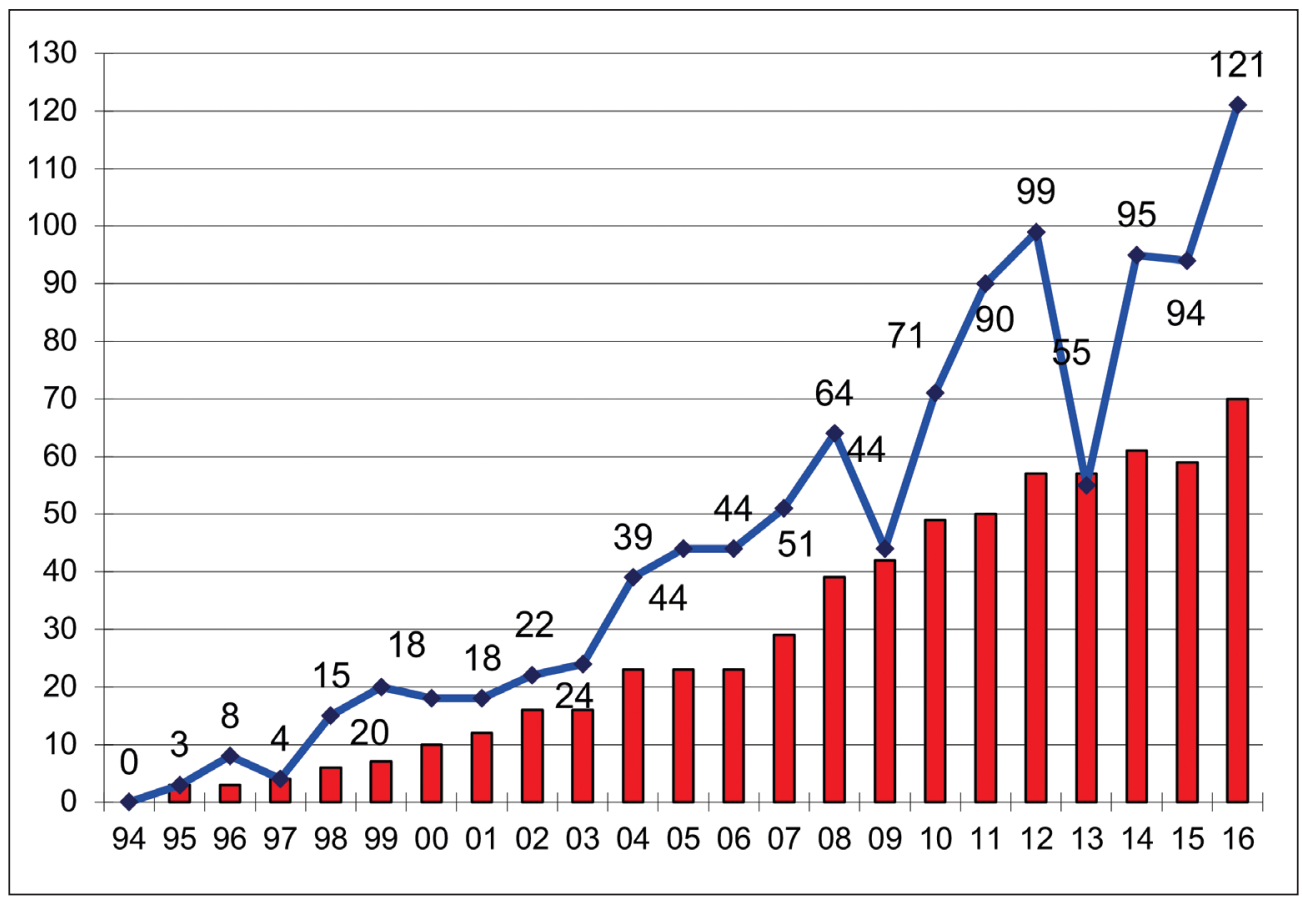

Figure 2. Continual increase of the Peregrine Falcon breeding population (red column) in the Czech Republic since 1994 and the total number of fledged young (blue line)

2. ábra A vándorsólyom költőpopulációjának folytonos növekedése a Cseh Köztársaság területén 1994 óta, valamint az összes kirepült fiatal egyed száma 


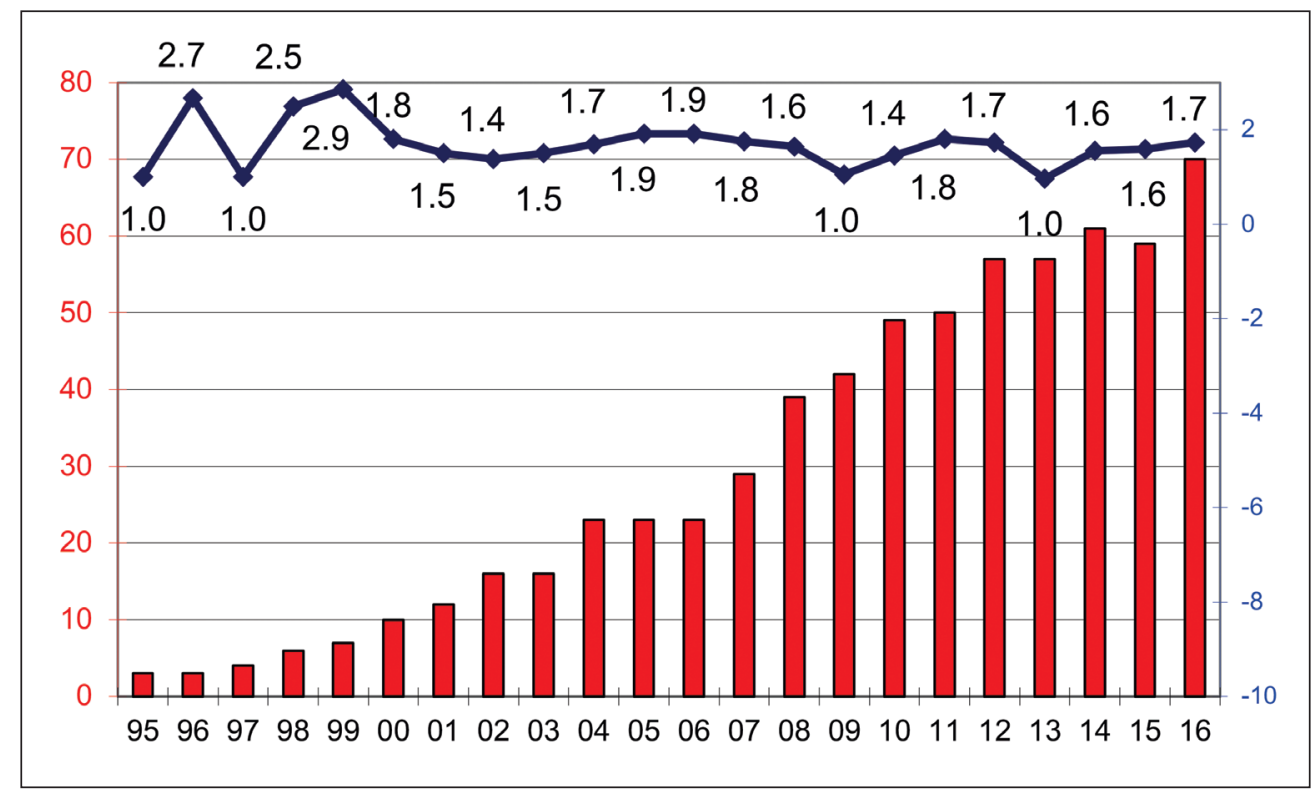

Figure 3. Continual increase of the Peregrine Falcon breeding population in the Czech Republic since 1994 (red column) and the average number of fledged young per nest (blue line)

3. ábra A vándorsólyom költőpopulációjának folytonos növekedése a Cseh Köztársaság területén 1994 óta, valamint az összes kirepült fiatal egyed átlagos száma/fészek

Mainly Common Raven (Corvus corax) nests are occupied in the rocky areas, but sandstone cavities and grassy ledges are also used for breeding.

The increase of Czech population is shown on Figure 2. Number of fledged chicks is increasing related to the increase of breeding pairs, but the average number of chicks fledged per successful nest is fluctuating (see Figure 3). Breeding data for the year 2016 are summarized in Table 1.

Table 1. Data about breeding population of Peregrine Falcon in the Czech Republic in 2016

1. táblázat A Cseh Köztársaságban 2016-ban költő vándorsólymok költési adatai

\begin{tabular}{|l|c|}
\hline & $\mathbf{2 0 1 6}$ \\
\hline Found pairs (total estimate) & $\mathbf{8 9}(\mathbf{9 1 )}$ \\
\hline Confirmed breeding pairs & $\mathbf{7 0}$ \\
\hline Found nests with known breeding result & $\mathbf{6 8}$ \\
\hline Successful nests & $\mathbf{4 5}(\mathbf{6 6 . 2} \%)$ \\
\hline Successful nests on rocks & $32(61.5 \%)$ \\
\hline Successful nests on buildings & $13(81.3 \%)$ \\
\hline Minimal number of fledged juveniles & $\mathbf{1 2 1}$ \\
\hline Average of juveniles / successful pairs & 2.80 \\
\hline Average of juveniles / all nests & 1.78 \\
\hline
\end{tabular}

According to the ringing recoveries, there is a strong influx of birds from Germany (mainly females). The question is, if the average number of chicks per successful nest of 1.6 is high enough for continuous increase of the population.

The increasing population and limited amount of natural breeding sites probably created new phenomenon - breeding on industrial buildings. First pairs were observed in northern Bohemia in 2008, but first breeding 


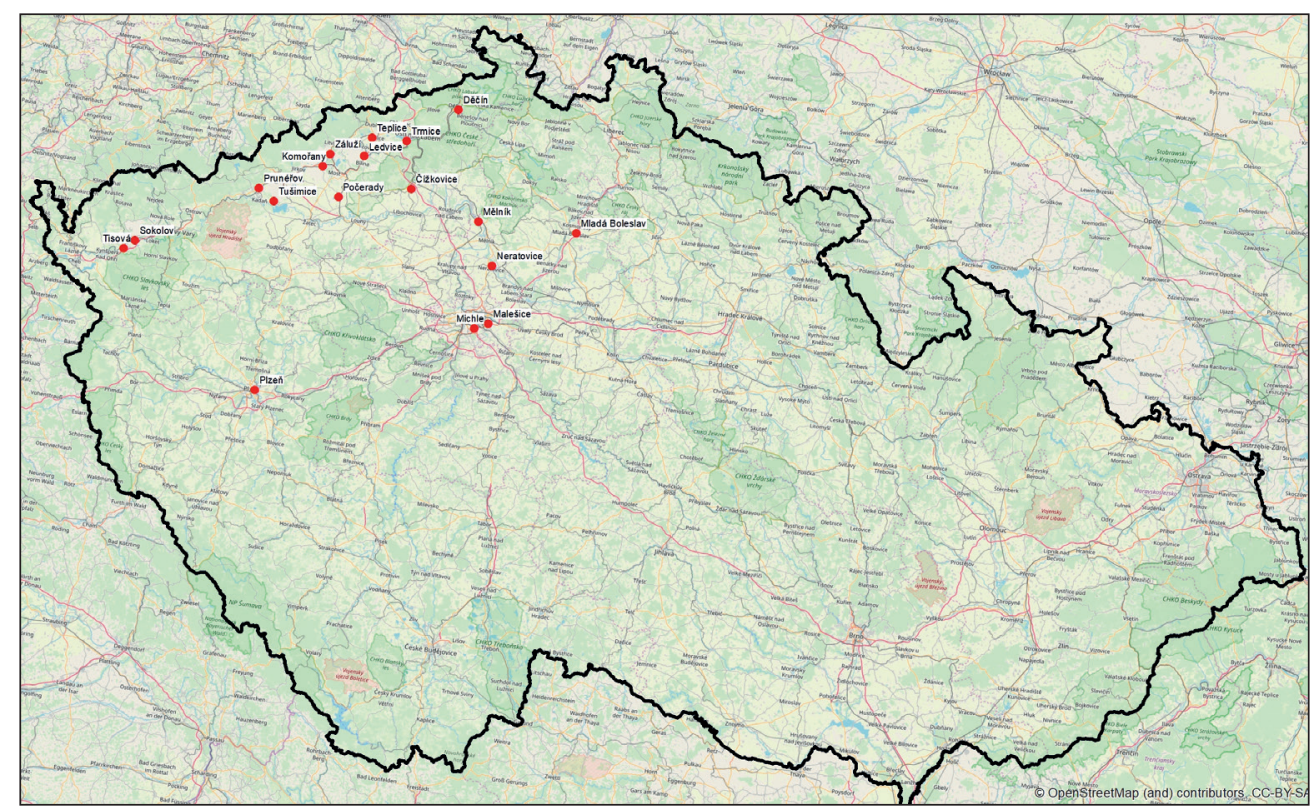

Figure 4. Distribution of Peregrine Falcon pairs breeding in nest boxes on industrial buildings in 2016. 17 out of 44 nest boxes installed on industrial buildings were occupied in 2016

4. ábra Az ipari épületekre kihelyezett költőládákban fészkelő vándorsólyom párok eloszlása 2016ban. Ebben az évben a 44 költőládából 17-et foglaltak el a madarak

was proved accidentally in 2010 on a chimney of Tušimice power plant. Planned demolition of the chimney had to be postponed by one month, because a Peregrine "nest" with two eggs was found in a roll of cables in the height of 300 meters above ground. Unfortunately the eggs did not hatch, probably because of bad shape of the nest. The chimney was demolished and the pair was breeding successfully in a nest box on a cooling tower next year. Number of pairs breeding on industrial buildings is increasing every year, new nest boxes are installed and successfully occupied. The phenomenon is spreading from the west and most of the pairs on industrial building are still situated in northwest Bohemia. The easternmost pair on an industrial building was breeding in Mladá Boleslav in 2016 despite the fact, that the nest boxes are installed on several buildings more to the east. Many adults breeding on the industrial buildings are of German origin. This probably explains, why breeding on industrial buildings is spreading from the west (Figures 1, 4).

The following numbers of pairs breeding in various types of eyries in 2016 are: 52 on natural nests on rock cliffs, 2 on natural nests in quarries, 16 in nest boxes on industrial buildings. No pairs bred on historical buildings or on a tree nests. Tree nesting has never been confirmed in the Czech Republic and all the eight published historical cases are doubtful (Horal \& Bělka 2013). 


\section{Ringing recoveries}

During the modern Peregrine Falcon history (1997-2018), 159 recoveries (66x Czech Republic Prague (CZP), 70x Hiddensee ringing centre (DEH), 8x Radolfzell ringing centre (DER), 2x Budapest ringing centre (HGB) a 13x Polish ringing center Gdansk (PLG) of 44 tagged birds (17 males, 24 females and 3 unsexed birds) have been obtained in the Czech Republic. Identified birds tagged with either ornithological and/or colour rings originated from four European countries - Germany 22 (21 DEH, 1 DER), CZP19, PLG 2 and HGB 1. The origin of birds involved in breeding pairs was systematically searched for only in Broumov hills and and in Jeseniky mountains in last few years. In the other regions, mostly accidental data obtained from e.g. photographs were used. The data are continuously refilled.

During the first years after species recovery, birds originating from NW direction (Germany, border region with Czech Republic - Sächsische Schweiz, Oybin) prevailed at the Czech rock nesting sites. In 2000-2015, total 15 of these birds were recorded at nest sites in Czech Republic. E.g. female 1CY (Oybin, born 2003) reared altogether 22 young (with 4 different males) between 2005-2012 at Teplické skály rocks. Later on, along with successful production of juveniles, the proportion of German birds at the natural nest sites started to decline gradually. E.g. in Broumov hills, German females in local breeding pairs were fully replaced by females from strong Jeseníky (Altvatergebirge) Mts. population. At certain nest sites, very old German-ringed Peregrines might be still present in the breeding pairs: e.g. male 0DP (Oybin 2004) was still in 2018 in the pair in Lužické hory (Lausitzer Gebirge) mts., or female 5FE (Sebnitz, 2005) bred in 2016 in Česká Lípa (Bömisch Leipa) region. These two birds are also the oldest known colour-ringed male and female, respectively, in the Czech Republic.

At present, Peregrines started to occupy nest boxes installed on high chimneys (17 pairs in 2017). Peregrine parents breeding at these nest sites (e.g. Litvínov / Leutensdorf, Most / Brüx, Teplice / Teplitz, Mladá Boleslav / Jung Bunzlau, Prague), are again mainly of German origin (DEH, DER). Most of them were even born in the same type of breeding habitat - in nest boxes on industrial buildings. These data are gathered systematically with the use of photo traps.

Data on four captive bred Peregrines involved in breeding in the area of the Czech Republic are known. Male EA32706 released in Germany (Pirna 1992) bred for six years (1995-2000) in the centre of Prague (alternating two different churches, see http://www. peske.wz.cz/peregrine.htm) and reared altogether nine chicks (plus two captive-bred were added, L. Peške pers. comm.). Female 5AW released in Poland (Milicz 2005) as a part of tree-breeding population restoration has bred in Broumov hills on a rock nest for six years (2009-2014) and reared altogether 11 young. Male 7CT from the similar project in Germany (Lieberose 2010) alternates two pairs / territories in Prague and has bred on a chimney for at least five years: in the first territory, one young was reared in 2013; in the other one, min 15 young were reared between 2014-2017. In 2018, most probably the same male bred here again but unsuccessfully (D. Rak pers. comm.). Male 7KH, released in Germany (Lilienstein, 1995) bred on the Czech side (Dolní Žleb) in 1997 (result of breeding not known) and was found dead in April 1999. Also, another female 7AX, released in Poland (Milicz 
2004) during the same project as 5AW (see above), was found dead in Jeseníky Mts (Skalka) in July 2009; it was not known whether this bird bred or not.

One of the most interesting recoveries is the breeding of female B8 born in northern Hungary (Bükk National Park, 2013). This bird formed a pair in the area of Moravian Karst / Mährischer Karst which has been abandoned by Peregrines for nearly 50 years. This female breeds successfully in this area annually since 2016; the distance to her place of origin is $326 \mathrm{~km} \mathrm{SE}$.

Recoveries revealed the fact that breeding Peregrine males are philopatric. Codes of 5 breeding males were read in 2016, four of them show that males usually settle not far from their birthplace $(11 \mathrm{~km}, 13 \mathrm{~km}, 23 \mathrm{~km}$ and $33 \mathrm{~km}$ ). Only the fifth male $-7 \mathrm{CT}$ (originating not from the wild but from the German reintroduction programme, see above) moved much further $-213 \mathrm{~km}$. On the contrary, females are less philopatric. Nine females observed in 2016 were breeding $16 \mathrm{~km}, 50 \mathrm{~km}, 71 \mathrm{~km}, 87 \mathrm{~km}, 95 \mathrm{~km}, 96 \mathrm{~km}, 98 \mathrm{~km}, 130 \mathrm{~km}$ and 270 $\mathrm{km}$ from their birth place. Another female C200746 born in 2007 in Český ráj hills settled in Poland (Glogów), $147 \mathrm{~km}$ apart, where she bred on a chimney of a copper mine along with German male 6JM (Lubmin 2010) until 2015.

In the town centre of České Budějovice (Budweis, South Bohemia), the repeated wintering of Peregrine Falcon female of the tundra / Arctic subspecies calidus was observed for minimum 6 consecutive winters (October to May). This bird was tagged with satellite transmitter at her breeding ground at Kolguyev Island, Barents Sea, North Russia in September 2014. During the winters $2014 / 2015$ to 2017/2018, her movements from her Arctic breeding place to her wintering site in South Bohemia and back could have been followed via www. movebank.org (under LifeTrack Peregrine falcon project, bird ID: 4203Kper03 ad). Unfortunately, this bird died by unknown reasons in the town centre of České Budějovice in the late January 2018.

\section{Acknowledgements}

Nature Conservation Agency of the Czech Republic, Ministry of the Environment of the Czech Republic, Czech Society for Ornithology, ALKA Wildlife, Bird Ringing Centre (National Museum, Prague), Ulrich Augst (Germany), and numerous field co-workers. 


\section{References}

Hlaváč, V. \& Beran, V. 2011. Návrat sokola stěhovavého - úspěch ochrany př́rody, nebo důsledek samovolného vývoje? [Recovery of the Peregrine - A successful story of nature conservation or a consequence of spontaneous development?].- Ochrana přírody 2011(1): 8-11. (in Czech)

Horal, D. (ed.) 2013. K hnízdním pokusům sokola stěhovavého (Falco peregrinus) v oblasti Novomlýnských nádrží a Pálavy na přelomu 20. a 21. století [Notes on the breeding attempts of Peregrine Falcons (Falco peregrinus) in the area of the Nové Mlýny reservoirs and the Pálava hills at the turn of $20^{\text {th }}$ century]. Crex 32: 82-94. (in Czech with English Summary)

Horal, D. \& Bělka, T. 2013. Poznámky k údajným hnízděním sokola stěhovavého (Falco peregrinus) na stromech na území České republiky [Notes on the tree-nesting Peregrine Falcons (Falco peregrinus) in the area of the Czech Republic]. - Crex 32: 95-104. (in Czech with English Summary)

Hruška, J., Melichar, D. \& Št’ovíček, V. 2000. Reintrodukce a hnízdění sokola stěhovavého (Falco peregrinus) v Plzni [Reintroduction and breeding of the Peregrine Falcon (Falco peregrinus) in Plzeň, Czech Republic]. - Buteo 11: 139-148. (in Czech with English Summary)

Mlíkovský, J. \& Hruška, J. 2000. Food of the Peregrine Falcon (Falco peregrinus) in Plzeň, Czech Republic. - Buteo 11: 125-128.

Peške, L. 1995. První prokázané hnízdění sokola stěhovavého (Falco peregrinus) v Praze [First known breeding of the Peregrine Falcon (Falco peregrinus) in Praha]. - Buteo 7: 56-66. (in Czech with English Summary)

Peške, L. 1997. Úspěšné vyhnízdění sokola stěhovavého (Falco peregrinus) v Praze v roce 1996 [Successful breeding of the Peregrine Falcon (Falco peregrinus) in Praha in 1996]. - Buteo 9: 109-114. (in Czech with English Summary)

Šaj, P. 2018. Sokol stěhovavý [Peregrine Falcon]. - Jeseníky / Rychlebské hory 1(1): 18-19. (in Czech)

Š́r, V. 1890. Ptactvo české. Svazek I. Rád I.: Draví [Czech Birds. Volume I. Order I. Raptors]. - Nakladatel knihkupec M. Knapp, Praha (in Czech)

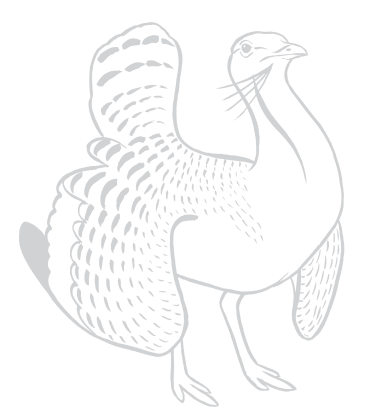

